\title{
Ants and their effects on an insect herbivore community associated with the inflorescences of Byrsonima crassifolia (Linnaeus) H.B.K. (Malpighiaceae)
}

\author{
G. Wilson Fernandes ${ }^{1}$, Marcílio Fagundes ${ }^{1}$, Magda K. Barcelos Greco ${ }^{1}$, \\ Marcos Soares Barbeitos ${ }^{2} \&$ Jean Carlos Santos ${ }^{1}$
}

\author{
${ }^{1}$ Ecologia Evolutiva de Herbivoros Tropicais/DBG, ICB/Universidade Federal de Minas Gerais, Caixa Postal 486, 30161-970 Belo Horizonte-MG, \\ Brasil. gwilson@icb.ufmg.br \\ ${ }^{2}$ Department of Biological Sciences, University at Buffalo, Cooke 109, Buffalo, NY, 14260.
}

\begin{abstract}
Ants and their effects on an insect herbivore community associated with the inflorescences of Byrsonima crassifolia (Linnaeus) H.B.K. (Malpighiaceae). The effects of ants on the insect community on inflorescences of Byrsonima crassifolia (Malpighiaceae) were tested in an ant exclusion experiment in a cerrado vegetation in southeastern Brazil. Forty-four species of insects (23 families) and nine species of ants (6 genera and 3 subfamilies) were found on the inflorescences of B. crassifolia. The exclusion of ants, primarily Camponotus sericeiventris and Camponotus spp., reduced the treehopper population to $20 \%$ of the original abundance. Ant exclusion and time influenced the abundance of chewing (Exclusion, $\mathrm{P}<0.001$; Time, $\mathrm{P}<0.002$ ), and sucking insects (Exclusion, $\mathrm{P}<0.02$; Time, $\mathrm{P}<0.01$ ). Twice as many chewing and sucking insects were found on ant-excluded inflorescences as compared to control inflorescences $(\mathrm{P}<0.001)$. One and half more sucking insects were found on ant-excluded than on control inflorescences. Only time significantly influenced the richness of chewing and sucking insects associated with B. crassifolia inflorescences. Inflorescences on control branches were significantly less attacked by herbivores than inflorescences on ant-excluded branches $(\mathrm{P}<0.001)$. Therefore, these results suggest that the presence of ants alters the structure of insect herbivore community associated with $B$. crassifolia.
\end{abstract}

KEYWORDS. Ant-treehopper mutualism; cerrado; community structure; insect herbivory.

RESUMO. Formigas e seus efeitos em uma comunidade de insetos herbívoros associada com as inflorescências de Byrsonima crassifolia (Linnaeus) H.B.K. (Malpighiaceae). Os efeitos de formigas na comunidade de insetos em inflorescências de Byrsonima crassifolia (Malpighiaceae) foram testados em um experimento de exclusão em uma vegetação de cerrado no Sudeste do Brasil. Quarenta e quatro espécies de insetos (23 famílias) e nove espécies de formigas (seis gêneros e três subfamílias) foram encontradas nas inflorescências de B. crassifolia. A exclusão das formigas, principalmente de Camponotus sericeiventris e de Camponotus spp. reduziu a população de membracídeos para $20 \%$ da abundância original. Exclusão das formigas e o tempo influenciaram a abundância de insetos mastigadores (exclusão, $\mathrm{P}<0,001$; tempo, $\mathrm{P}<0,002$ ) e sugadores (exclusão, $\mathrm{P}<0,02$; tempo, $\mathrm{P}<0,01$ ). Insetos mastigadores e sugadores foram encontrados duas vezes mais em inflorescências com formigas excluídas quando comparados com inflorescências controle $(\mathrm{P}<0,001)$. Insetos sugadores foram encontrados 1,5 vezes mais em inflorescências com formigas excluídas do que no controle. Apenas o tempo influenciou significativamente a riqueza de insetos mastigadores e sugadores associados com as inflorescências de $B$. crassifolia. Inflorescências em ramos controle foram significativamente menos atacadas por herbívoros do que inflorescências em ramos com formigas excluídas $(\mathrm{P}<0,001)$. Portanto, estes resultados sugerem que a presença das formigas influencia a estrutura da comunidade de insetos herbívoros associados com B. crassifolia.

PALAVRAS-CHAVE. Cerrado; estrutura de comunidade; herbivoria por insetos, mutualismo formiga-membracídeo.

Ants may exert strong influences on the structure, composition, and dynamics of insect communities. They can directly affect the insect herbivores, and mediate interactions between herbivores and host plants (e.g., Bentley 1977; Stephenson 1982; Koptur 1984; Kelly 1986; Strauss 1987; Davidson \& McKey 1993; Del Claro \& Oliveira 1999; 2000). Many plant species have structures, such as domatias and extrafloral nectaries, that attract ants which may then deter herbivores (Janzen 1966, 1969; Elias \& Gelband 1975; Barton 1986; O'Dowd \& Willson 1989). Plants species without these structures may be protected by ants that establish a mutualistic relationship with hemipterans that live on the plant (Messina 1981; Fritz 1983; Grant \& Moran 1986; Buckley 1987).

Despite the enormous diversity of plants and ants (Wilson 1987), and high levels of herbivory (Coley \& Aide 1991), relatively few ant-plant-herbivore systems have been studied in the tropics (e.g., Longino 1989; Davidson et al. 1991;
Davidson \& McKey 1993; Del Claro \& Oliveira 1999, 2000). Most of these studies have focused on ant-plant interactions mediated by extra-floral nectaries (e.g., Oliveira \& OliveiraFilho 1991), while studies on herbivory on plant reproductive parts have not received the deserved attention.

We studied the influence of ants on the insect community associated with the inflorescences of a neotropical plant, Byrsonima crassifolia (Linnaeus) H. B. K. (Malpighiaceae). Preliminary observations revealed an abundant fauna of ants and of chewing and sucking insect herbivores associated with the inflorescences of this plant. The aims of this study were two-fold: 1) identify the insect species associated with inflorescences of B. crassifolia; and 2) experimentally test two hypotheses on the effect of ants on the insect community associated with the host plant inflorescences; developed below.

The mutualisms between ants and hemipterans is an 
important mechanism of plant defense against herbivorous insects. Ants protect the honeydew-excreting from parasites and predators (Messina 1981; Del-Claro \& Oliveira 1999, 2000). By removing potential herbivorous species, ants may protect the hemipteran's food resource by reducing overall herbivory on the host plants (Boecklen 1984; Hölldobler \& Wilson 1990; Cushman 1991). Thus, our first hypothesis predicts that ants would have a positive influence on treehopper abundance. Increased numbers of ants and treehoppers would then have a negative influence on the abundance of other herbivorous insects due to ant predation and/or treehopper competition with other herbivores. The second hypothesis predicts that ants would lower the rates of attack by herbivores on the inflorescences.

\section{METHODS}

Study area and the system. The study was conducted in 200 ha of cerrado (savannah) vegetation in the Estação Florestal de Experimentação (EFLEX) of the Instituto Brasileiro do Meio Ambiente e Recursos Naturais Renováveis (IBAMA), in Paraopeba, Minas Gerais, southeastern Brazil. This is a tropical area with a well defined dry season (June to September) at an elevation of $740 \mathrm{~m}$ above sea level. The annual average temperature and precipitation are $20.6{ }^{\circ} \mathrm{C}$ and $1,236 \mathrm{~mm}$, respectively (Silva et al. 1987).

Byrsonima crassifolia (Linnaeus) H. B. K. (Malpighiaceae) is a widespread cerrado shrub with about two meters high, in the cerrado vegetation (Goodland \& Ferri 1979). There were approximately $2.25 \mathrm{~B}$. crassifolia individuals per $1,000 \mathrm{~m}^{2}$ in the study area (D. J. Domingos unpubl. data). This species flowers in the rainy season and it is polinized primarily by bees that are attracted by the oil produced by the floral glands of the plant located at the calix basis (Sazima \& Sazima 1988).

Treehoppers (Hemiptera, Membracidae) were very common on the plant and at least four species could be separated in the field by morphological differences. As these insects were always found at the base of the inflorescences, we argue that the proximity of the treehoppers to the reproductive parts would favor the protection of the inflorecences. Among the four membracid species, one was the most frequent. Many other insects were found on the plant, including ants, herbivores, parasites, and predators. The insects listed in this study were deposited at the insect collection of the Universidade Federal de Minas Gerais, Belo Horizonte - MG, Brazil.

Sampling. An exclusion experiment was set up to observe the effect of ants on the insect community and herbivory levels on the inflorescences of B. crassifolia. Eight B. crassifolia plants were randomly chosen in the field and examined every week for associated insects and herbivory from October to December 1990. Field observations were carried out from 9:00h AM to 16:00h PM. Selected plants did not harbor ant nests, which could interfere with insect community structure and herbivory levels.

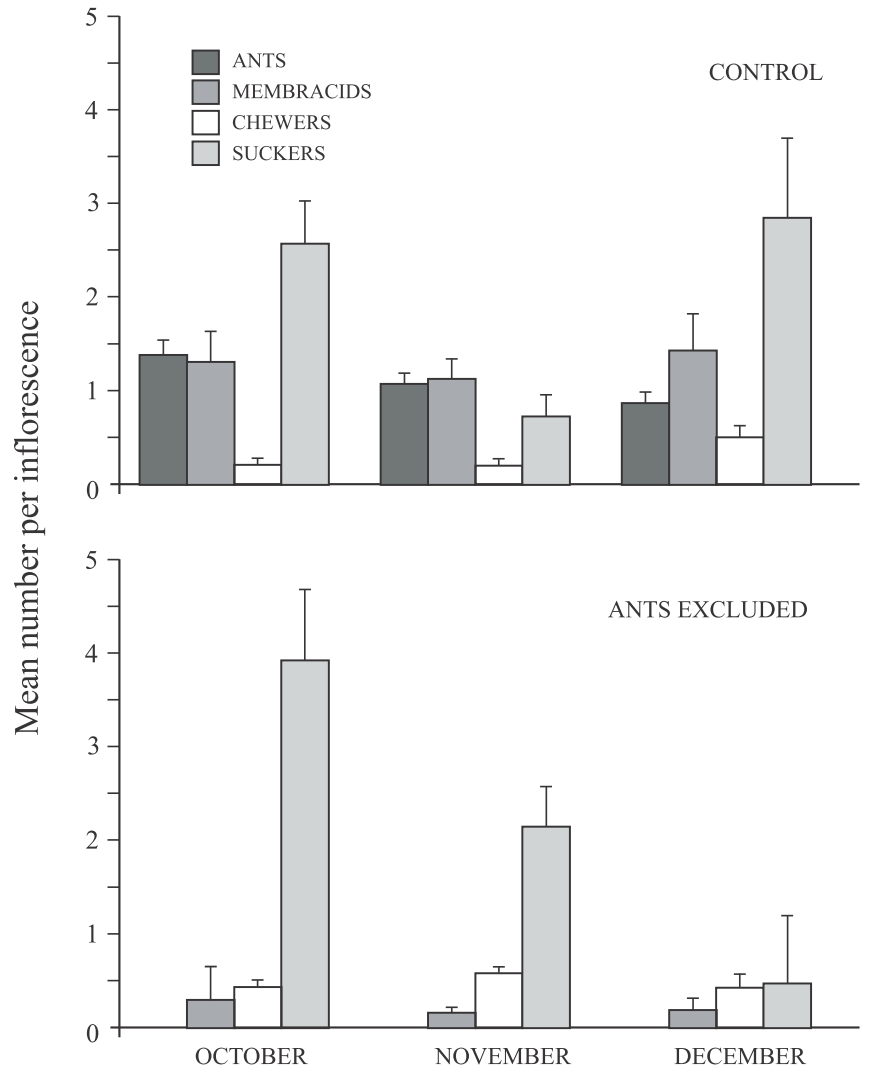

Fig. 1. Average number ( $\pm 1 \mathrm{SE}$ ) of individuals per inflorescence on control and on ant-excluded inflorescences.

Two pairs of flowering branches were randomly selected per plant, and ants were excluded from one of the pairs of the branches (ant-excluded) with $15 \mathrm{~cm}$ long "tanglefoot" (Tanglefoot Company Grand Rapids, Michigan, USA) rings. Ants were allowed to circulate freely on the control branches. Hence, we had 16 pairs of branches compared on 8 plants. Tanglefoot rings were renewed every week throughout the study. Neighboring grass bridges providing aerial access of ants to the trunk of treated plants were regularly pruned. In average, over 30 inflorescences were found on one-meter long branch. Five inflorescences were randomly collected from each control and ant-excluded branches at the end of each month ( $\mathrm{n}=234$; six were discarded due to sampling problems). Sampled inflorescences were covered with $10 \times 15 \mathrm{~cm}$ plasticbags, trimmed off, and the insects immediately killed with ethyl acetate.

Inflorescences were taken to the laboratory and kept in a freezer until dissected under a stereomicroscope. Insects were counted and separated into morphospecies. Insects were divided into four large groups: ants, treehoppers, chewing insects (primarily coleopterans and lepidopterans), and sucking insects ("hemipterans" and gallers). Predators, parasites and tourists were not considered in our analyses because we could not predict with certainty their role in the community during our study. Treehoppers were separated from 
the other sucking insects because of their general mutualism with the ants. Inflorescence buds, flowers, and fruits were counted, and herbivore attack measured on each of them. However, since many branches lacked one or more inflorescence parts, these measurements were pooled to obtain a balanced design. The overall herbivore attack was estimated as the percentage of structures damaged on each branch. The distribution of this variable was normalised through rootsquare arc-sin transformation. As our study aims to test for differences between rather than within plants, data on inflorescences were averaged for each treatment in each plant.

Two-way repeated measures ANOVA was employed to access the separate and pooled effects of ant exclusion and time. Whenever data did not meet the assumptions of this test, profile analysis was performed using non-parametric statistics to determine the pooled effect of time and isolation (Scheiner \& Gurevitch 1993).

\section{RESULTS}

Insect community. Forty-four species of insects comprising at least 23 families were observed on the inflorescences of $B$. crassifolia. The majority of the insects were herbivores (86.4\%), the remaining species $(13.6 \%)$ were either and predators or parasites (Table I). Nine ant species were observed (6 genera and 3 subfamilies) foraging on $B$. crassifolia inflorescences (Table II). Camponotus sericeiventris (Guzrin 1838) and Camponotus spp. could not be distinguished in the field and hence were counted together. The genus Camponotus and Brachymyrmex were the most abundant representing $80.5 \%$ of all the ant community. Camponotus ssp. tended the treehoppers and used oils produced by the flower calix glands. Brachymyrmex sp. did not tend the treehoppers, whereas it was observed that Cephalotes spp. 1 also utilized the oils produced by the inflorescence glands.

Ant-treehopper association and the insect community. Ants were very abundant on the inflorescences. Ants species cooccurred on the plant studied. An overall average of $3.72 \pm$ 1.02 ants per control inflorescence was found, whereas as expected no ants were found on the ant-excluded inflorescences $(n=234)$. The number of ants per control inflorescence did not vary statistically throughout the study (Kruskal-Wallis ANOVA, $\mathrm{X}^{2}=0.58, \mathrm{p}=0.75$ ).

The abundance of treehoppers was significantly influenced by ant exclusion. There were approximately five times more treehoppers on control inflorescences $(1.219 \pm 3.846)$ than on ant-excluded inflorescences $(0.235 \pm 0.936)(\mathrm{U}=5894.5$, adjusted $\mathrm{p}<0.05$, Fig. 1$)$. These results partially support the hypothesis that ants may exert strong effects on insect herbivore communities.

Ant exclusion and time influenced the abundance of chewing insects (exclusion, $\mathrm{U}=11.0$, adjusted $\mathrm{p}=0.27$; time, $X^{2}=7.22$, p $<0.05$, Fig. 1). An interactive effect between ant exclusion and time in transition from the first day to the second was observed ( $\mathrm{U}=12.5$, adjusted $\mathrm{p}<0.05)$ but no difference was

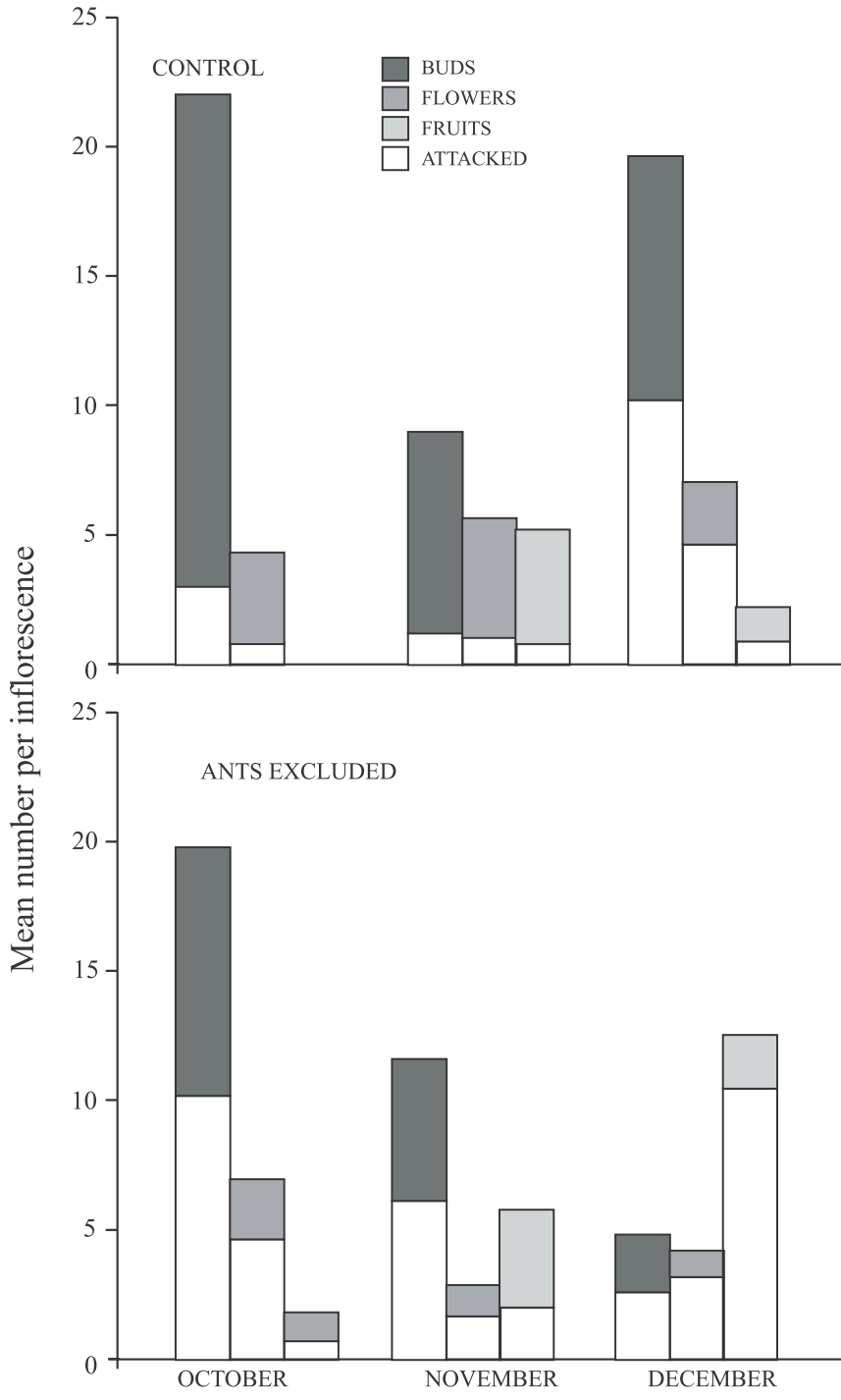

Fig. 2. Average number of buds, flowers, and fruits produced on control and on ant-excluded inflorescences (filled bars). The average number of bud, flower, and fruits attacked by herbivores are represented by the empty portion of the bar.

found between the second and the third days $(\mathrm{U}=22.0$, adjusted $\mathrm{p}=0.291)$. There was no significant effect of ant exclusion on sucking insect abundance $(\mathrm{F}=2.43, \mathrm{p}=0.14)$. However, the abundance of these insects varied with time $(\mathrm{F}=5.10, \mathrm{p}<0.05)$.

Resource availability and differential herbivory. We dissected over 3,000 buds, flowers, and fruits from 234 inflorescences. Control and ant-excluded branches produced very different number of buds, flowers, and fruits $(\mathrm{F}=64.84$; $\mathrm{p}<0.001$, Fig. 2). The amount of reproductive parts was larger in control than treatment. Time also influenced the production of these structures ( $F=12.37 ; p<0.001$, Fig. 2) while we observed an interaction effect between these variables $(\mathrm{F}=10.44 ; \mathrm{p}<0.005$, Fig. 2).

Herbivore attack on inflorescence parts was influenced by 
Table I. Order, family and number of morphospecies of insects observed on inflorescences of Byrsonima crassifolia in Paraopeba (MG)-Brazil. $\mathrm{C}=$ Chewers, $\mathrm{S}=$ Suckers, $\mathrm{P}=$ Predators and Parasites

\begin{tabular}{llcc}
\hline Order & Family/ & Morpho & Feeding \\
& Superfamily & -species & guild \\
\hline Blattodea & Blattidae & 1 & $\mathrm{C}$ \\
Coleoptera & Anthicidae & 1 & $\mathrm{C}$ \\
& Chrysomelidae & 9 & $\mathrm{C}$ \\
& Curculionidae & 1 & $\mathrm{C}$ \\
& Staphylinidae & 1 & $\mathrm{P}$ \\
Diptera & Cecidomyiidae & 3 & $\mathrm{~S}$ \\
Hemiptera & Lygaeidae & 1 & $\mathrm{~S}$ \\
& Miridae & 1 & $\mathrm{~S}$ \\
& Pentatomidae & 1 & $\mathrm{~S}$ \\
& Not identified & 1 & $\mathrm{~S}$ \\
& Aphididae & 1 & $\mathrm{~S}$ \\
& Cercopidae & 1 & $\mathrm{~S}$ \\
& Cicadellidae & 2 & $\mathrm{~S}$ \\
& Membracidae & 4 & $\mathrm{~S}$ \\
Lepidoptera & Psyllidae & 1 & $\mathrm{~S}$ \\
Thysanoptera & Not identified & 7 & $\mathrm{C}$ \\
Hymenoptera & Thripidae & 1 & $\mathrm{~S}$ \\
& Chalcidoidea & 1 & $\mathrm{P}$ \\
& Eulophidae & 1 & $\mathrm{P}$ \\
& Eurytomidae & 1 & $\mathrm{P}$ \\
Total & Mymaridae & 1 & $\mathrm{P}$ \\
& Proctotrupoidea & 2 & $\mathrm{P}$ \\
& Not identified & 1 & $\mathrm{P}$ \\
\hline & 23 & 44 & \\
& & &
\end{tabular}

ant exclusion $(\mathrm{F}=116.79, \mathrm{p}<0.001)$ and time $(\mathrm{F}=10.76, \mathrm{p}<0.001)$. Inflorescences on control branches were significantly less attacked by herbivores than inflorescences on ant-excluded branches (Fig. 2). These findings support the contention that ant presence diminished herbivore attack on inflorescences, in this system.

\section{DISCUSSION}

Although the primary function of flower calix glands is pollinator atraction (Sazima \& Sazima 1988), they may produce substances that attract many species of ants. In B. crassifolia, at least two species of Camponotus were attracted to the inflorescences, and vigorously defended the floral glands and their associated treehoppers. Although Camponotus spp. and Brachymyrmex spp.1 showed similar relative abundances, the presence of Camponotus spp. was more homogeneous throughout the experiment. They recruited in average 4 to 5 individuals per inflorescence while Brachymyrmex spp. 1 only occurred on three shrubs, and recruited 15 to 22 individuals per inflorescence (but see Wilson 1971). Camponotus is the most effective and abundant ant genus associated with extrafloral nectaries in the cerrado (Oliveira \& Brandão 1991; Oliveira \& Pie 1998). This is the first report of these ants utilizing the floral glands of Byrsonima crassifolia. Otherwise, studies related to ants frequency among plants and activity patterns must be addressed for a better understanding of the system.

Hemipterans and ants may be strongly associated (Messina 1981; Risch \& Carroll 1982; Cushman \& Whithan 1989). Many studies have reported a positive correlation between treehopper and ant abundances (e.g., Messina 1981; Grant \& Moran 1986; Buckley \& Gullan 1991). The presence of ants on $B$. crassifolia inflorescences resulted in a significant increase in the abundance of treehoppers. On inflorescences without ants, treehopper abundance was reduced to $20 \%$. On ant-excluded inflorescences, treehoppers were frequently observed being attacked by predators and parasitoids (see Del-Claro \& Oliveira 2000). Camponotus spp. reduced the amount of predation and parasitism by vigorously attacking other insects that approached the inflorescences and treehoppers. Buckley (1990) has shown that, in the absence of ants, treehoppers are subject to significant higher predation rates. Nevertheless, differences in treehopper numbers could also be caused by differential recruitment or reproduction, hence deserving additional studies.

Ants negatively influenced the abundance of chewing and sucking herbivores. On the other hand, the abundance of the first group was more severely affectes. This finding was probably due to a combination of the ant's aggressive behaviors towards any non-treehopper species. The removal of the herbivores associated with the inflorescence of Peixotoa tomentosa (Malpighiaceae) depends on the size, morphology and behavior of the associated ants (Del-Claro 1998). Another possibility is an influenced by an increased population size/ dominance of treehoppers. Many studies have shown that ants modify the dominance relations of insects on their host plants (e.g., Longino 1989; Craig et al. 1991; Davidson et al. 1991) as well as the insect community structure (see Clark et al. 1982; Risch \& Carroll 1982; Fritz 1983; Strauss 1987; Woodman \& Price 1992). The ants associated with the inflorescences of $B$. crassifolia positively affected the numerical association with treehoppers and the community of herbivorous insects. Thus, the data support the hypothesis that ants influence the insect herbivore community on $B$. crassifolia inflorescences. However, possible competitive effects between treehoppers and the other herbivores in the community must be evaluated.

Table II. Relative abundance of ants $(\mathrm{n}=741)$ on Byrsonima crassifolia in Paraopeba, MG, Brazil.

\begin{tabular}{llc}
\hline Subfamily & Morpho-species & $\begin{array}{c}\text { Relative } \\
\text { abundance (\%) }\end{array}$ \\
\hline Formicinae & Camponotus sericeiventris & \\
& and Camponotus sp. & 40.50 \\
& Brachymyrmex sp. & 40.50 \\
Myrmicinae & Sp. 01 & 0.50 \\
& Cephalotes sp. 1 & 7.05 \\
& Cephalotes sp. 2 & 7.05 \\
Pseudomyrmicinae & Pheidole sp. & 1.25 \\
& Pseudomyrmex sp.1 & 2.90 \\
& Pseudomyrmex sp.2 & 0.50 \\
\hline Total & & 100 \\
\hline
\end{tabular}


Ants exerted a protective role against insect herbivory on the reproductive organs of $B$. crassifolia. Protection by ants resulted in a three-fold decrease in herbivore attack rates on fruits on control inflorescences, and warranted great number of mature fruits without attack by herbivores insects (see also Keeler 1981). Studies on seed viability are, however, necessary to determine herbivore impact on buds, flowers, and fruits. The protection against herbivory given by Camponotus spp. was the result of their aggressiveness against herbivorous insects. Furthermore, ant protection was amplified by a secondary effect, i.e., the mutualism between Camponotus spp. and treehoppers. By defending treehoppers from potential competitors and/or enemies, ants amplified the plant defensive shield against other insect herbivores (see Messina 1981). Nevertheless, more detailed studies are necessary to determine the effect of treehopper herbivory on the host plant in the presence and absence of ants.

Acknowledgments. We thank Denise J. Domingos, T. P. Craig, J. K. Itami, P. W. Price, and two anonymous reviewers for their encouragement and comments on earlier versions of the manuscript. Insects were identified by A. F. Yamamoto (UFMG) and L. M. Araujo (UFMG). We thank the EFLEX for logistical support. This work was supported by a CNPq-PRPq/UFMG scholarship to MKBG and by CNPq (52 1772/95-8, 304851/2004-3) and FAPEMIG (CRA 2519/97).

\section{REFERENCES}

Barton, A. M. 1986. Spatial variation in the effect of ants on an extrafloral nectary plant. Ecology 67: 495-504.

Bentley, B. L. 1977. The protective function of ant visits to extrafloral nectaries of Bixa orellana. Ecology 65: 27-38.

Boecklen, W. J. 1984. The role of extrafloral nectaries in the herbivore defense of Cassia fasciata. Ecological Entomology 9: 243-249.

Buckley, R. C. 1987. Interactions involving plants, hemipterans, and ants. Annual Review of Ecology and Systematics 18: 111-35.

Buckley, R. C. 1990. Ants protect tropical Homoptera against nocturnal spider predation. Biotropica 22: 207-209.

Buckley, R. C. \& P. Gullan. 1991. More aggressive ant species (Hymenoptera: Formicidae) provide better protection for soft scales mealybugs (Homoptera: Coccidae, Pseudococcidae). Biotropica 23: $282-286$.

Clark, D. B.; C. Guayasamin; O. Pazmino; C. Donoso \& Y. P. Villacis. 1982. The tramp ant (Wasmania auropunctata): autoecology and effects on ant diversity and distribution on Santa Cruz Island, Galapagos. Biotropica 14: 169-207.

Coley, P. D. \& T. M. Aide. 1991. Comparisons of herbivory and tropical broad-leaved forest, p. 25-48. In: P. W. Price; T. M. Lewinsohn; G. W. Fernandes \& W. W. Benson (Edit.). Plantanimal interactions: evolutionary ecology in tropical and temperate regions. New York, John Wiley \& Sons, $639 \mathrm{p}$.

Craig, T. P.; J. Itami; L. M. Araújo \& G. W. Fernandes. 1991. Development of the insect community centered on a leaf-bud gall formed by a weevil (Coleoptera: Curculionidae) on Xylopia aromatica (Annonaceae). Revista Brasileira de Entomologia 35: $311-317$.

Cushman, J. H. 1991. Host-plant mediation of insect mutualisms: variable outcomes in herbivore-ant interactions. Oikos 61: 138144.

Cushman, J. H. \& T. G. Whithan. 1989. Conditional mutualism in a membracid-ant association: temporal, age-espcific, and densitydependent effects. Ecology 70: 1040-1047.

Davidson, D. W. \& D. McKey. 1993. The evolutionary ecology of simbiotic ant-plant relationships. Journal of the Hymenoptera Research 2: 13-83.
Davidson, D. W.; R. B. Foster; R. R. Snelling \& P. W. Lozada. 1991 Variable composition of some tropical ant-plant symbioses, $\mathrm{p}$. 145-162. In: P. W. Price; T. M. Lewinsohn; G. W. Fernandes \& W. W. Benson (Edit.). Plant-animal interactions: evolutionary ecology in tropical and temperate regions. New York, John Wiley \& Sons, 639 p.

Del-Claro, K. 1998. A importância do comportamento de formigas em interações: formigas e tripes em Peixotoa tomentosa (Malpighiaceae) no cerrado. Revista de Etologia 1: 3-10.

Del-Claro, K. \& P. S. Oliveira. 1999. Ant-Homoptera interactions in a neotropical savanna: the honeydew-producing treehopper, Guayaquila xiphias (Membracidae), and its associated ant fauna on Didymopanax vinosum (Araliaceae). Biotropica 31: 135-144.

Del-Claro, K \& P. S. Oliveira. 2000. Conditional outcomes in a neotropical treehoper-ant association: temporal and speciesspecific variation in ant protection and hemipteran fecundity. Oecologia 124: 156-165.

Elias, T. S. \& H. Gelband. 1975. Nectar: its production and functions in trumpet creeper. Science 189: 298-290.

Fritz, R. S. 1983. Ant protection of a host plant's defoliator: consequence of an ant-membracid mutualism. Ecology 64: 789-797.

Goodland, R. \& M. G. Ferri. 1979. Ecologia do cerrado. Belo Horizonte, Ed. Itatiaia.

Grant, S. \& V. C. Moran. 1986. The effects of foraging ants on arboreal insect herbivores in an undisturbed savanna. Ecological Entomology 11: 83-93.

Hölldobler, B. \& E. O. Wilson. 1990. The ants. Cambridge, The Belknap Press of Harvard University Press, $732 \mathrm{p}$.

Janzen, D. H. 1966. Coevolution of mutualism between ants and acacias in Central America. Evolution 20: 249-275.

Janzen, D. H. 1969. Allelopathy by myrmecophytes: the ant Azteca as an allelopathic agent of Cecropia. Ecology 50: 147-153.

Keeler, K. H. 1981. Functions of Mentzelia nuda (Loasaceae) postfloral nectaries in seed defense. American Journal of Botany 68: 295299.

Kelly, C. A. 1986. Extrafloral nectaries: ants, herbivores and fecundity in Cassia fasciculata. Oecologia 69: 600-605.

Koptur, S. 1984. Experimental evidence for defense of Inga (Mimosoideae) saplings by ants. Ecology 65: 1787-1793.

Longino, J. T. 1989. Geographic variation and community structure in an ant-plant mutualism: Azteca and Cecropia in Costa Rica. Biotropica 21: 126-132.

Messina, F. J. 1981. Plant protection as a consequence of an antmembracid mutualism: interactions on goldenrod (Solidago sp.). Ecology 62: 1433-1440.

O’Dowd, D. J. \& M. F. Willson. 1989. Leaf domatia and mites on Australian plants: ecological and evolutionary implications. Biological Journal of the Linnean Society 37: 191-236.

Oliveira, P. S. \& C. R. F. Brandão. 1991. The ant community associated with extrafloral nectaries in the brazilian cerrados, p. 182-212. In: C. R. Huxley \& D. F. Cutler (Edit.). Ant-plant interactions. Oxford, Oxford Univ. Press, $601 \mathrm{p}$.

Oliveira, P. S. \& A. T. Oliveira-Filho. 1991. Distribution of extrafloral nectaries in the woody flora of tropical communities in western Brazil, p. 163-175. In: P. W. Price; T. M. Lewinsohn; G. W. Fernandes \& W. W. Benson (Edit.). Plant-animal interactions: evolutionary ecology in tropical and temperate regions. New York, John Wiley \& Sons, $639 \mathrm{p}$.

Oliveira, P. S. \& M. R Pie. 1998. Interactions between ants and plants bearing extrafloral nectaries in cerrado vegetation. Anais da Sociedade Entomológica do Brasil. 27: 161-176.

Messina, F. J. 1981. Plant protection as a consequence of an antmembracid mutualism: interactions on goldenrod, Solidago sp. Ecology 62: 1433-1440.

Risch, S. J. \& C. R. Carroll. 1982. Effect of a keystone predaceous ant, Solenopsis geminata, on arthropods in a tropical agroecosystem. Ecology 63: 1979-1983.

Sazima, M. \& I. Sazima. 1988. Oil-gatthering bees visit flowers of glandular morphs of the oil-producing Malpighiaceae. Botanica Acta 102: 106-111.

Scheiner, S. M. \& J. Gurevitch. 1993. Design and Analysis of 
Ecological Experiments. $1^{\text {st }}$ Edition. New York, Chapman \& Hall, $445 \mathrm{p}$.

Silva Jr., M. C.; N. F. Barros \& J. F. Cândido. 1987. Relações entre parâmetros do solo e da vegetação de cerrado na Estação Florestal de Experimentação de Paraopeba-MG. Revista Brasileira de Botânica 10: 125-137.

Stephenson, A. G. 1982. The role of the extrafloral nectaries of Catalpa speciosa in limiting herbivory and increasing fruit production. Ecology 63: 663-669.
Strauss, S. Y. 1987. Direct and indirect effects of host-plant fertilization on an insect community. Ecology 68: 1670-1678.

Wilson, E. O. 1971. The insect societies. Cambridge, Harvard University Press, $548 \mathrm{p}$.

Wilson, E. O. 1987. Causes of ecological success: the case of the ants. Journal of Animal Ecology 56: 1-9.

Woodman, R. L. \& P. W. Price. 1992. Differential larval predation by ants can influence willow sawfly community structure. Ecology 73: $1028-1037$. 